\title{
Conceptions of parents of adolescent students about the sexuality of their children
}

\author{
Concepções de pais de adolescentes escolares sobre a sexualidade de seus filhos
}

Pollyanna de Siqueira Queirós ${ }^{1}$, Laurena Moreira Pires², Marcos André Matos², Ana Luiza Neto Junqueira², Marcelo Medeiros², Márcia Maria de Souza²

Objective: to know the conceptions of parents of adolescent students about the sexuality of their children. Methods: it is a qualitative research modality Strategic Research, using focus groups guided by a semi structured instrument with 15 parents of adolescent students. The data were analyzed by content analysis in which the following categories emerged: "Understanding aspects related to sexuality"; "Difficulties for dialogue"; "Facilities for dialogue"; and "The tasks of the family and the school to support the theme." Results: parents had superficial knowledge and misconceptions on the subject. Great difficulty of dialogue between parents and children has been identified, justified by ignorance and timidity of parents and the lack of opening of the adolescent, still, there was recognition of family responsibility in this context. Conclusion: there is need for expansion of intersectoral work involving segments of the education, health and universities to support families with information about sexuality in the school context.

Descriptors: Adolescent; Sexuality; Family Relations; Sex Education; Nursing.

Objetivo: conhecer a concepção de pais de adolescentes escolares sobre a sexualidade dos seus filhos. Métodos: pesquisa qualitativa, modalidade Pesquisa Estratégica, utilizando grupos focais norteados por instrumento semiestruturado, com 15 pais de adolescentes escolares. Os dados foram analisados por Análise de Conteúdo, em que emergiram as categorias "Compreendendo aspectos relacionados à sexualidade"; "Dificuldades para o diálogo"; "Facilidades para o diálogo"; e "As atribuições da família e da escola no apoio a temática". Resultados: os pais apresentaram conhecimento superficial e conceitos errôneos sobre o tema. Foi identificada uma grande dificuldade de diálogo entre pais e filhos, justificada pelo desconhecimento e timidez dos pais e falta de abertura do adolescente, ainda assim, houve reconhecimento da responsabilização da família neste contexto. Conclusão: há necessidade de ampliação do trabalho intersetorial envolvendo segmentos da educação, saúde e instituições de ensino superior a fim de apoiar as famílias com informações sobre sexualidade no contexto escolar.

Descritores: Adolescente; Sexualidade; Relações familiares; Educação sexual; Enfermagem.

\footnotetext{
*Extracted from the dissertation Concepções de pais de adolescentes escolares sobre temáticas relacionadas à sexualidade humana, Universidade Federal de Goiás, 2012.

${ }^{1}$ Universidade do Estado de Mato Grosso. Tangará da Serra, MT, Brazil.
${ }^{2}$ Universidade Federal de Goiás. Goiânia, GO, Brazil.

Corresponding author: Márcia Maria de Souza

Rua 227 Qd. 68 S/N Setor Leste Universitário, CEP: 74605-080. Goiânia, GO, Brazil. E-mail: marcia.fen@gmail.com
} 


\section{Introduction}

Adolescence is a period between childhood and adulthood, considered of great importance in human development, with expression and experience of the body and remarkable changes in the biological aspect and subjective in nature ${ }^{(1-2)}$. It is a process of physical and relational experimentation, but it should be understood in a systemic view of the adolescent process, in which the subject of this process is seen in its uniqueness as well as their interactions with their family background and social, from a historical and dialectic perspective $\mathrm{e}^{(2-3)}$.

The sexual behavior of adolescents suffers several influences with unfolding in the economic, socio-cultural, religious and psychological spheres, that, when associated with an early onset of sexual activity makes them vulnerable to behavioral situations as the acquisition of sexually transmitted diseases, the Human Immunodeficiency Virus, Acquired Immunodeficiency syndrome (AIDS) and early pregnancy ${ }^{(4)}$. To cope with this problem, the literature already points to the importance of the family being present and engaging with issues of interest to children, because the family environment is considered a privileged space for the transmission of values, keeping in mind several vulnerabilities inherent to the stage of human development itself $f^{(5)}$.

In this sense, the family is considered the main agent of socialization of its members, especially during adolescence, in the absorption of ethical and humanitarian values and in the building of bonds of solidarity ${ }^{(5-7)}$. The interaction and dialogue between parents and children provide trusts for both, especially when they approach delicate and behavioral issues such as the phenomenon of sexuality ${ }^{(6,8)}$.

Many times parents do not know how to act upon the manifestations of sexuality of their children ${ }^{(9)}$, feeling unprepared to meet the demands and curiosity of children because they feel intellectually and emotionally unable to guide, lead, direct and monitor this stage of life.
In this sense, the family influence has a direct impact on the understanding and building of the sexuality of the adolescent, and that the unsafe knowledge and sexual behaviors can lead to vulnerability to Sexually Transmitted Diseases, Acquired Immunodeficiency Syndrome and early pregnancy.

The involvement of parents in discussions about behavioral issues involving sexuality in adolescence is considered pertinent. Thus, an approximation with the parents allowed them to know this problem by different dimensions, especially to know their weaknesses and needs.

Therefore, knowing the conceptions of parents on this subject allowed them to recognize their knowledge, restrictions, taboos, and especially if this issue is being discussed within the family. In addition, this strategy may enable, in the family, the awakening of the need of prevention and identification of constant situations of varied vulnerabilities to which their adolescent children are constantly exposed as acquisition of sexually transmitted diseases, teenage pregnancy and violence, including sexual.

The aim of this study was to know the conception of parents of adolescent about sexuality of their children.

\section{Methods}

This is a qualitative research in which subjects were parents of students aged between twelve and eighteen years of age enrolled in a public institution of basic education, morning and afternoon, in a capital of the Central Region of Brazil.

Data were collected through focus groups between March and September 2011. The study included 15 parents of adolescents, being 14 mothers and one father.

An invitation to participate in the meeting was written by the researcher with the support of an educational coordinator and delivered at the time of the parents' meeting. 
Three meetings were held with an average duration of one hour, in order to exhaust the discussions to be contemplated from the proposed objectives, that even saturating the data the researchers made themselves available to hold other meetings in order to keep discussing the issues, if parents were interested to continue the group discussions.

In order to make the participants feel at ease, a wide, comfortable, free of noise room was chosen. All participants, moderator and parents sat in a circle so that there could be a visual contact between everyone, being the moderator the one who led the socialization process without, however, intervening in the process. In all the meetings moments of reception were provided, holding varied techniques and dynamics so that parents could feel welcomed and at ease with the intention to minimize possible tensions or shyness of the participants.

The researcher was the moderator who guided the conduct of focus groups following a semi structured script with guiding questions: "What do you mean by sexuality"? "What do you mean by Sexually Transmitted Diseases"? "Do you talk with your children about sexuality, about the prevention of Sexually Transmitted Diseases and pregnancy"? "What difficulties, facilities and needs do you have when talking to your children about issues involving sexuality"? "In your opinion, who are the ones responsible for the education of adolescents about sexuality, prevention of Sexually Transmitted Diseases and early pregnancy"?

In order to have a register of the meetings, the moderator also had the support of three research assistants who performed the recording of meetings in electronics and conventional recorder with the consent of all participants. As a complementary technique, the register of the movements of the group and expression of verbal and nonverbal communication were carried out by a research assistant, nursing student assistant, trained for that function.

The notes in the field diary were also taken from the time of planning the meetings until the end of each meeting. The transcript of the interviews was made in full so as not to lose the participants' answers.

Data analysis was based on assumptions of Content Analysis - Thematic Modality ${ }^{(10)}$, which is to identify the core of meanings of a dialogue from three chronological axes (pre-analysis, exploration of the material and treatment, inference and interpretation of results) in order to identify the units of meaning and themes in the statements of the research subjects.

For the identification of excerpts of the statements presented in the discussion an alphabetical code was adopted, followed by an Arabic number, which refers to the chronological order so as to protect the identity of the subjects.

The study complied with the formal requirements contained in the national and international regulatory standards of research involving human subjects.

\section{Results}

The statements of the participants were strictly selected so that they represented their essence, especially in order to meet the objectives of the research.

The analysis of the statements of the parents of adolescent students revealed four theme categories inserted in the central theme "Sexuality and dialogue between parents and adolescent children", as follows: Understanding aspects related to sexuality; Difficulties for dialogue; Facilities for dialogue; and family and school tasks to support the theme.

\section{Category 1 - Understanding aspects related to sexuality}

The statements expressed the knowledge on the meaning and reflection of the sexuality theme. The parents referred to sexuality as something related only to sex, changes in the human body, genitals and sexually transmitted diseases, as shown in the lines: Comes from sex? I can't explain (P2). I think it involves the genitals of 
men and women (P8).

In discussions sexually transmitted diseases were also addressed, such as the types of diseases that the group knew and the information they had about the same. The statements show that parents have great lack of information on sexually transmitted diseases, with only superficial knowledge: Aids is the worst, the most dangerous (P1). I worry about all diseases, but mainly with AIDS, because it is a disease that has no cure and the others that have cure with hard work, but AIDS does not have (P9).

The results revealed that parents care about their children before the vulnerability to contracting sexually transmitted diseases, however, they refer more concern to the Acquired Immunodeficiency Syndrome, because it has no cure and also for being the best known among them.

In the present investigation, the statements also show the lack of adequate and effective knowledge in relation to other diseases transmitted through sex: If hepatitis is transmitted by sex? I do not know (P2). I do not know very well, syphilis is a wound, isn't it? I do not know (P3).

In addition to the Acquired Immunodeficiency Syndrome and other sexually transmitted disease, parents revealed a concern with dating/sex, early pregnancy and the need for prevention: Nowadays dating is very different from the past, sex only after marriage, not nowadays (P8). I talked to her [daughter] that having intercourse without a condom, makes her pregnant (P2).

\section{Category 2 - Difficulties for dialogue}

Parents pointed to the difficulty of the family in inserting the theme sexuality among the issues discussed with the children. The factors listed here that hinder dialogue between parents and teens about the promotion of sexual and reproductive health are shame and shyness: Because I find it hard to talk to her, for being ashamed (P2). Once I tried to speak, but it didn't come out I was blocked (P5). I think it is not easy, my generation is different, I think in the generation of my child will be easier, I have difficulty (P3).

Another issue pointed out by parents as harmful to dialogue refers to the characteristics of children, for example, shyness: He is a little closed (P3). She is so bad-tempered, if she were more open, it would be easier for me. She [daughter] is not shy, but she does not like to talk to me about this issue (P2). With me [mother] she [daughter] is already shy and she does not like talking and she has a certain block with the father, she is afraid to talk to him and talk to him certain things (P7).

At the same time, the parents show the fear of encouraging their children to sexual practices is a limitation factor for the dialogue: Because many mothers think so, they think that talking about condoms is encouraging, because talking to her, so I can be encouraging her to sex (P2). I think that showing condoms incentives it, people say that no, but it does (P3).

Although showing these difficulties, parents also report what they need to do to overcome the situation: We need to learn other things. You [indicating to the researcher] need to make more meetings, talk to us (P9). I [mother] find it very interesting these meetings as well, because we can share, talk. It is important that we discuss this issue, learn more about the disease (P3).

The need for a greater family opening to overcome the difficulties related to the dialogue was also reported: I [mother] had to open up more to her [daughter]. I think I had to talk more, to have more dialogue, be more open (P2). I think I had to open myself more, I had to forget a little bit of that nervousness and try to talk to her [daughter] (P5).

\section{Category 3 - Facilities for dialogue}

In this category, some situations that favor or make dialogue with their children easier are covered, among them, lack of shame, tranquility, the habit of storytelling and the approach with the children: What makes it easy is that I am open. You start slowly with other issues first until you get it (P8). I tell stories, I talk about sex openly, tell stories of someone I heard, I speak, this happened and that happen and it can happen to us too, I know stories of old women who transmit diseases, because they use boys as well (P3).

The availability of parents to an open dialogue was also found in this study. The situations already 
experienced by them when they were young and the difficulties experienced made this moment easier: Both he [father] and I [mother], we are not ashamed, we talk. I suffered a lot in my time, when I was turning into a young lady, I wanted to know about menstruation and my mother did not speak to me, no one spoke to me, that's why I'm pretty liberal with my children (P9). I didn't have any instruction from my parents, I learned outside, and I do not want my children to go through this. Parents should start the conversation, should not wait for the child because it takes too long and then it is already too late, parents should start (P8).

\section{Category 4 - Family and school tasks to support the theme}

In this category, the statements show the family, that is, mother and father, followed by the school, as the ones who are responsible for the education of their adolescent children in relation to the promotion of sexual and reproductive health, prevention of sexually transmitted diseases and teenage pregnancy as well as the importance of these guidelines. $I$ [mother] think the ones responsible to talk about it are the parents, the greatest responsibility lies with the parents, but so it must also be addressed at school, but the greatest responsibility belongs to the family (P7). I think in the first place, the parents, and also the school (P9). I think that in the first place come the parents, they must learn at home, after that at the church and then the school (P8).The role of mother and father is the same, it is important; I think that you have to guide the children on pregnancy prevention, explaining little by little, I think we have to guide, to give advice, is a very important role (P1).

The statements showed that within the family context, the greater responsibility for the education of children belongs to the mothers: I think it's the mother because the father does not know how to talk about this [the husband] "you go, I cannot talk." My husband is more quiet, so he did not say anything [All participants make gestures agreeing that the responsibility to talk is more with mothers] (P3). He [the father] leaves the responsibility to us [mother], but I think it had to be father and mother, who have to talk about everything, but he leaves all responsibility on us (P2).

\section{Discussion}

The theme of sexuality is related to various aspects in human life, especially in adolescence, and therefore it should be recognized as an inherent part to the process of development of the personality and not just as a synonym for sex or sexual activity ${ }^{(11)}$.

The experience of sexuality based on erroneous beliefs and misconceptions trigger irreversible consequences and favors conditions of vulnerability, that because sex without the use of condom, ignorance of risks, misinformation and the lack of prevention programs in most Brazilian schools increase vulnerability of young people to contract a sexually transmitted disease and early pregnancy ${ }^{(5,12)}$.

There is great concern by the family regarding early pregnancy, overcoming fear in relation to infection by sexually transmitted diseases ${ }^{(5)}$, especially the Acquired Immunodeficiency Syndrome, results also emerged among the participants of this study.

Thus, the fragmented view of sexuality phenomenon, as evidenced in the statements of the participants, in which parents consider only biological phenomena, makes comprehension difficult, and the restlessness, doubts and desire of adolescents undermine the dialogue between parents and children.

The positive communication between parents and children about sexuality theme provides emotional support and a sense of necessary support when it comes to these issues and it is considered a protective factor to reduce the risk of sexual behaviors ${ }^{(13-15)}$.

As shown in previous studies ${ }^{(5,14)}$, teenagers counted especially on the mothers to clarify questions, because often it is up to them to keep the daily responsibility for the education of the children, while the father is disciplining and controlling, less empathic and permissible that the mother. In turn, it was identified that especially among mothers and daughters the dialogue has a protecting effect on the use of condom and other contraceptive methods ${ }^{(14)}$. 
The statements of the participating parents of this study indicate that these subjects have an interest in talking to their children about sexuality, but not all feel of them comfortable in doing so. Often the barriers in relation to dialogue between parents and children is given by feeling unprepared to meet the requirements of the children, and consider themselves intellectually and emotionally unable to guide, lead and direct them on issues of sexuality, often do not know how to act on the manifestations of sexuality of their children ${ }^{(8-9,14)}$, as it corroborates the statements found among the participating parents.

Parents are afraid to explain about the barrier contraception, such as condoms, because they believe that when talking about this subject or showing the condom they could encourage the child to have sex. So, they do not establish a healthy dialogue with their children, or may take a stricter stance with deliberate attempts to control and restrict adolescent sexual behavior ${ }^{(8)}$.

Added to these difficulties of dialogue, the fear of the children to seek their parents to clarify doubts on issues related to sexuality, which is associated to the fear they feel of reprisal due to taboos and prejudices $^{(9,16)}$. In these contexts, the teenager feels intimidated and fearful of reprisals to get from the parents the necessary guidance ${ }^{(16)}$, which in turn make them go after their peers to share doubts and discoveries, which in many times can trigger the transmission of erroneous information to these subjects.

In this sense, the familiar opening for discussion of the subject is necessary, reaffirming the need for a conduct based on an open dialogue, responding to these adolescents what they need to know, not in a prejudiced way, establishing a positive parental relationship and effective communication in the family. Consequently, there is the promotion of autonomy and self-discovery, contributing for the development of criticism reflections for the improvement of their choices, thus reducing the likelihood of involvement with vulnerable sexual behavior.
The parents need to be aware, having the knowledge to go beyond the biological model, in order to feel safe and involved in the sex education of their children, opening up safe spaces for discussion and reflection about sexuality. Thus, one should seek strategies to overcome these difficulties reported by parents, as guidance and support from health professionals, school and other parents experiencing the same problem and once in a group could find support and guidance based on their experiences.

It was evident that in many cases parents are seeking to implement a dialogue on sexuality, trying to provide information to which they did not have access, because they understand that they should not repeat the model of sexual orientation received. When parents have a close relationship with the children and manage to establish positive communication, they are more important than friends when it comes to dialogue and conversations about sexuality, which for many parents must take place even before the adolescent search for information ${ }^{(5)}$.

The family is the initial locus of education of the adolescent, considered the primary source responsible for establishing communication links with its members to make them critical, reflexive, problem-solving and decision-taking(17). Despite the representative role of the family in adolescent life, school is also considered one of the primary collaborative spaces for teenagers.

When considering the school environment as the main domain for the socialization of the students, especially adolescents, the work of the sexuality theme in this environment is a great strategy for prevention of diseases and problems related to sexual behavior among adolescents ${ }^{(11,13,18)}$.

One has to consider that the school needs to expand health promotion and activities of schoolchildren, coordinating these activities with the nurses of the Family Health Strategy, for example, in order to involve the families of adolescents in the educational activities.

The nurse as a professional directly linked to 
the health of the family can watch and take care of both the adolescents and their families through counseling, exchange of ideas, clarifying doubts and promoting actions, considering that the very model of care in the Brazilian public health, above all favoring the approach of this professional with the community ${ }^{(6,19)}$.

It is essential to consider that both the family and school and health professionals can contribute so that the adolescent experience sexuality and their personal relationships satisfactorily, sharing knowledge in order to guide their children to exercise their sexuality with responsibility, dignity and pleasure ${ }^{(6)}$.

The construction of inter-institutional partnerships in the formation of an integrated health system and education has been reported as important in order to reduce potential risks to health and collaborating in the education of future healthy citizens $^{(11,18)}$. Thus, strategies of articulation and strengthening partnerships among family, school, health facilities and universities to be established, facing the phenomena still very present in Brazilian reality with high prevalence of sexually transmitted diseases and early pregnancy.

\section{Conclusion}

This study included the proposed objectives and contributed to know the conception of the parents on issues involving behavioral issues such as sexuality.

The views of parents emerged from the statements show a central theme category called "Discussing sexuality" and four subcategories: "Conceptualizing sexuality”; "Difficulties for dialogue"; "Facilities for dialogue" and "Responsibility for the education of adolescents."

In the first category we apprehend that parents had a superficial knowledge about human sexuality, relating it only to a biological vision and sometimes misconceptions.

In the second category, a great difficulty of parents in dialogue with the children was identified, highlighting factors such as shyness between them.
They showed great interest and support of health professionals, indicating the professional nurse to assist in the expansion of their knowledge.

The third category showed the importance of dialogue with the children, although superficially. That is, the conversation between parent and child is only in the transfer of information without deepening the behavioral issues such as prevention, sex, sexually transmitted diseases and early pregnancy.

The fourth category, showed, in the conception of the parents, that the responsibility and a sexual education are essential for the family, followed by the school and religious institution.

It was possible to identify from the categories found the need for future studies to develop the mechanisms of creation, expansion and strengthening of intersectoral work involving segments of education, universities and professionals of the Family Health Strategy, particularly the nurse, with the implementation of the School Health Program and support to the families to build an integrated network with expanded information in the context of sex education.

\section{Collaborations}

Queirós PS, Pires LM and Souza MM contributed to the design, collection, analysis and interpretation of data and writing of the article. Matos MA, Junqueira ALN and Medeiros M contributed to the interpretation of data, writing, relevant critical review of the intellectual content and final version of the article to be published.

\section{References}

1. Brêtas JRS, Ohara CVS, Jardim DP, Junior WA, Oliveira JR. Aspectos da sexualidade na adolescência. Ciênc Saúde Coletiva. 2011; 16(7):3221-8.

2. Mota CP, Rocha M. Adolescência e jovem adultícia: crescimento pessoal, separação-individuação e o jogo das relações. Psic Teor Pesq. 2012; 28(3):35766. 
3. Silvia MAI. Adolescence: resignify it to understand it and ac [Editorial]. Rev Enferm UFPE On line [Internet]. 2012 [cited 2012 May 20];6(3):13. Available from: http://www.revista.ufpe.br/ revistaenfermagem/index.php/revista/article/ view/2646/pdf_1089

4. Almeida SA, Nogueira JA, Silva AO, Torres GV. Orientação sexual nas escolas: fato ou anseio? Rev Gaúcha Enferm. 2011; 32(1):107-13.

5. Ressel LB, Junges CF, Sehnem GD, Sanfelie C. A influência da família na vivência a sexualidade. Esc Ana Nery. 2011; 15(2):245-50.

6. Nery IS, Feitosa JJM, Sousa AFL, Fernandes ACN. Approach to sexuality in the dialogue between parents and adolescentes. Acta Paul Enferm. 2015; 28(3):287-92.

7. Salomão R, Silva MAI, Cano MAT. Sexualidade do adolescente na percepção dos pais, sob a perspectiva de Foucault. Rev Eletr Enf [Internet]. 2013 [citado 2015 jul 15]; 15(3):609-18. Disponível em: http://dx.doi.org/10.5216/ree. v15i3.20978

8. Rogers AA, Ha T, Stormshak EA, Dishion TJ. Quality of parent-adolescent conversations about sex and adolescent sexual behavior: an observational study. J Adolesc Health. 2015; 57(2):174-8.

9. Costa MA, Rabelo NS, Moraes ICM, Siqueira FCM, Cabral ESM. Fatores que obstam na comunicação entre pais e filhos adolescentes sobre sexualidade. Rev Enferm UFSM. 2014; 4(1):123-32.

10. Bardin L. Análise de conteúdo. São Paulo: Edições 70; 2011.

11. Rufino CB, Pires LM, Oliveira PC, Souza SMB, Souza MM. Educação sexual na prática pedagógica de professores da rede básica de ensino. Rev Eletr Enf [Internet]. 2013 [citado 2015 mai 10]; 15(4):98391. Disponível em: http://dx.doi.org/10.5216/ ree.v15i4.19941
12. Araújo AC, Lunardi VL, Silveira RS, Thofehrn MB, Porto AR, Soares DC. Implicações da sexualidade e reprodução no adolescer saudável. Rev Rene. 2012; 13(2):467-44.

13. Araújo AVS, Pinto MB, Andrade LDF, Santos NCCB. O papel dos pais na educação sexual de adolescentes: uma revisão integrativa. Rev Univ Vale Rio Verde. 2015; 13(2):117-28.

14. Widman L, Choukas-BradleyS, NoarS, Nesi J, Garrett K. Parent-adolescent sexual communication and adolescent safer sex behavior: a meta-analysis. JAMA Pediatr. 2016; 170(1):52-61.

15. Gavin LE, Williams JR, Rivera MI, Lachance CR. Programs to strengthen parent-adolescent communication about reproductive health: a systematic review. Am J Prev Med. 2015; 49(2):6572.

16. Macedo SRH, Miranda FAN, Júnior JMP, Nóbrega VKM. Adolescência e sexualidade: scripts sexuais a partir das representações sociais. Rev Bras Enferm. 2013; 66(1):103-9.

17. Jesus FB, Lima FCA, Martins CBG, Matos KF, Souza SPS. Vulnerabilidade na adolescência: a experiência e expressão do adolescente. Rev Gaúcha Enferm. 2011; 32(2):359-67.

18. Souza MM, Munari DB, Souza SMB, Esperidião E, Medeiros M. Qualificação de professores do ensino básico para educação sexual por meio da pesquisa-ação. Cienc Cuid Saúde. 2010; 9(1):91-8.

19. Marques JF, Queiroz MVO. Cuidado ao adolescente na atenção básica: necessidades dos usuários e sua relação com o serviço. Rev Gaúcha Enferm. 2012; 33(3):65-72. 